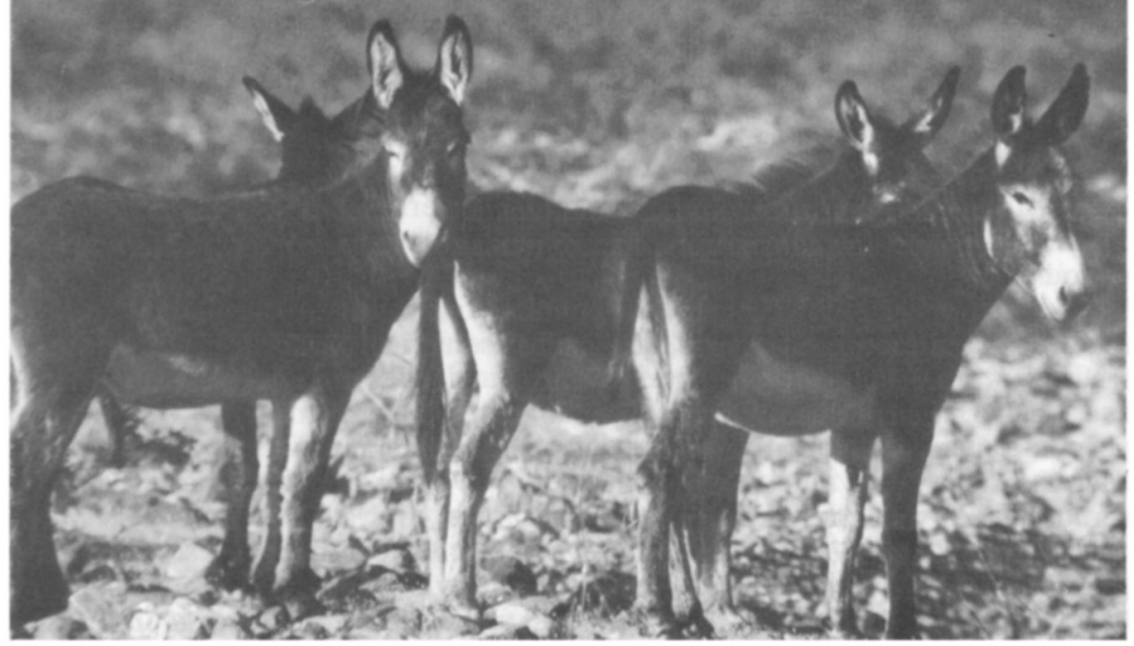

\title{
The Burros in Death Valley
}

\section{Stephen Mills}

In California's Death Valley burros, the introduced wild donkeys, are driving out the native desert bighorn sheep, as well as destroying the vegetation. A sentimental public has so far ensured their protection and prevented the Park Service solving the problem. Now the Service is proposing to remove the burros completely by giving away those they can trap and shooting the rest.

The burros of Death Valley may soon be staring down the gun-barrels of the United States Park Service. After years of debate and delay the proposal to shoot them has finally been adopted in a Draft Environmental Impact Statement distributed for public comment last winter.

The Spaniards brought the burros Equus asinus to Mexico in the 16th century. Later they became popular as pack animals with the mineral prospectors in the Western deserts. But by the 1920s motorized transport had made them obsolete, and they were turned loose to fend for themselves. This they succeeded in doing because, being closely related to their wild counterpart $E$. a. somalicus, they are well adapted to survival in the desert, able to last for days without water and to withstand up to 30 per cent dehydration. They lose little salt when they sweat and so can reabsorb water very quickly when they find it. One animal was seen to drink 30 litres of water non-stop in five minutes.

More than 2100 burros now inhabit Death Valley National Monument, the highest concentration anywhere in the United States. The valley, which comprises two million acres of the most interesting desert topography in America, lies between the Panamint and Armagosa mountain ranges, on the border between California and Nevada, much of it $200 \mathrm{ft}$ below sea-level, where summer temperatures can reach $130^{\circ} \mathrm{F}$. Such extreme conditions have evolved a fragile fauna and flora which the burros are damaging seriously - destroying vegetation, trampling top-soil, fouling water-holes and competing, all too successfully, with native animals, in particular the desert bighorn sheep Ovis canadensis. Daily observations by Dr Patricia Moehlman ${ }^{2}$ on a group of 220 Death Valley burros over a 
20-month period showed that they spent 51 per cent of their time feeding, 36 per cent standing, 9 per cent walking and 4 per cent 'other'. The lengthy period devoted to feeding causes the biggest problem. Burros both graze and browse and, because they are not highly efficient digesters of protein, they require a large intake of many different desert plants; analysis of just a few faecal samples revealed 40 species of shrubs and grasses. They are estimated to eat 2650 tonnes of Death Valley vegetation each year. In 1973, Park Service personnel made comparative counts of plants inside and outside a burro-proof enclosure. Transects outside had only a third as many grasses, a quarter as many shrubs and 27 times the number of dead shrubs as equivalent ones inside.

The 9 per cent walking also causes problems. Much of the desert terrain is protected by the 'desert pavement', either a layer of fungus or a fragile skin often only one pebble thick. Damage to this exposes the few vital grains of topsoil beneath it to erosion by wind and rain. Dr Moehlman observed that waterholes were the focus of burro society throughout the year. Males would gather for their daily drink in the hope of a fight or to ambush available females, and mothers caring for foals rarely wandered more than half a kilometre from water. As the holes gradually dry up in the summer the pressure on those that remain becomes acute, to the disadvantage of the less aggressive indigenous animals. That some pretty frenzied activity was included under 4 per cent 'other', was shown by the fact that 63 per cent of Dr Moehlman's females were pregnant in 1970. Indeed, a study by Dr Susan Woodward ${ }^{4}$ showed that in a herd of 80 burros in the Chemehuevi Mountains, south of Death Valley, females were producing two foals every three years. With females maturing as young as 10 months the population could double in five years. Dr Woodward warned that 'unceasing management and control' were required to avoid the effect of a 'sustained drought' which overgrazing by burros was likely to cause.

Perhaps the burro has had its gravest impact on the bighorn sheep. Once widely hunted for its magnificent curled horns, the desert bighorn - paler than the northern mountain race - has become rare and elusive, confined to the foothills and stony fastnesses. Its decline is attributed to disturbance, the transmission of parasites by sheep, and the loss of forage, water and range to the burros - a factor cited in reports from all the western States where burros are found. The late Dr Charles Hansen's bighorn survey in Death Valley in 1972-73 indicated that, where there were no burros, bighorns had declined by about 50 per cent since 1850 , but in areas of comparable vegetation and wildness where burros were present the decline was as great as 96 per cent. There are now only about 500 bighorns left in the Monument and its surrounding desert.

Why then has no decisive action been taken? The answer lies in the convoluted ramifications of what might be termed 'the bureaucracy of the burro'. It started in the 1950s when Mrs Velma Johnson of Reno, Nevada, brought the mistreatment of wild horses being rounded up and slaughtered for the pet-food trade to the attention of Congress. The consequent legislation called, in her honour, The Wild Horse Annie Act of 1959, outlawed the use of motor vehicles and aircraft in the pursuit of horses or burros. But public sentiment took the cause much further than Mrs Johnson ever intended, and in 1971 comprehensive immunity from shooting or disturbance was granted to both feral animals under the Wild Free-Roaming Horse and Burro Act. This underlined the sentimental motivations for preserving the horses and burros by describing them as 'living symbols of the historic and pioneer spirit of the West'. It also stated, quite 
wrongly, that they were an 'integral part of the natural system of the public lands'.

Since then a tangled web of legislation has grown up around the animals, culminating in the setting up, in 1981, of a high-powered committee by the National Academy of Sciences to find out whether there are not in fact too many wild horses and burros despoiling the western ranges. Clearly the Park Service believes there are too many burros in Death Valley. Between 1939 and 1969 more than 4000 were trapped or shot and the population kept down to about 700 . When culling became unacceptable to the public the Park Service had to resort to an adoption programme which involves catching the donkeys one by one, getting them into pens and persuading visitors to take them home as pets. Four hundred and fifty-one burros have been removed since 1973 - not enough to solve the problem but, at $\$ 350$ per animal, sufficient to cost the Monument $\$ 130,000$. The scheme has also necessitated secondary legislation to ensure that the new owners do not abuse their donkeys.

In the meantime, because of their accessibility, their pleasant location and their similarity to the endangered Somali ass, the burros have become attractive

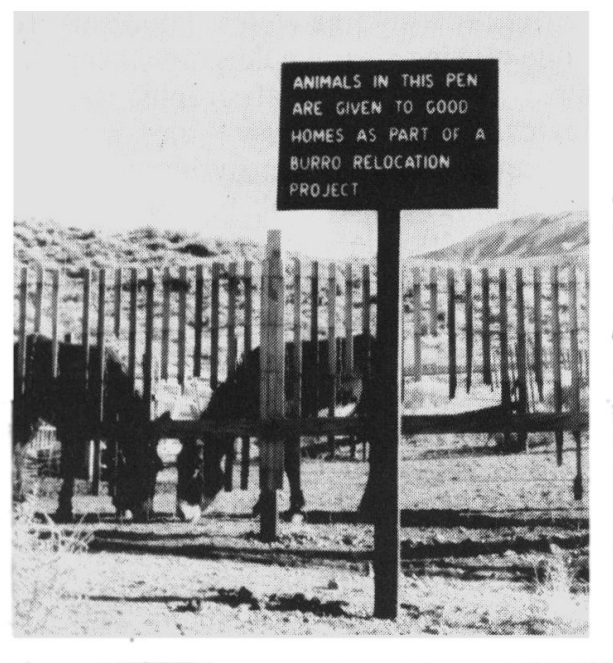

inset: The animals are rounded up and given away; but culling may be still be necessary.

below: Burros destroy both vegetation and the protective crust of the desert soil.




to research scientists. Thus the vested interest of education may also have cosseted them; few researchers have chosen, as Dr Woodward ${ }^{4}$ did, to describe the protection laws as 'the result of emotional appeals from a poorly informed public'. The bighorns, on the other hand, have received little research attention since people do not want to risk doing a doctorate on an animal so difficult to study. Only in 1980 did a detailed study begin on bighorns, and now several in Death Valley are fitted with radio transmitters, and are under the scrutiny of Dr Charles Douglas of the University of Nevada. ${ }^{1}$

The story of the Death Valley burros involves a topsy-turvy situation in which the strange alliance between a sentimental public and curious scientists has permitted an introduced species, the burro - an avowed nuisance - to benefit from extensive legislation, detailed research and a lot of money. Yet a rare indigenous species, the bighorn, which increasingly needs all three, has received practically nothing. The new Impact Statement ${ }^{3}$ hopes to redress the balance. This considers various alternatives: burros could be sterilized and allowed to die out naturally; they could be translocated using immobilizing drugs; some could be retained in two 8000 -acre viewing areas for visitors to enjoy. But the Park Service feels that such schemes would take up too much time and money and still leave the problem unsolved. It would be almost impossible to sterilize or immobilize all the burros, while viewing areas would simply keep the issue alive, and erosion in the enclosures might become catastrophic. So the Service proposes immediate and total removal. If it gets its way - and, with the vagaries of public opinion this is still not certain - then as many burros as possible will be trapped and put up for adoption. The rest, probably about 1500 , will be shot. Selective boundary fencing, along 40 miles of the northern section at first, followed by 63 miles of continuous fencing elsewhere if necessary, will then be erected to keep out other burros and stray cattle. At $\$ 9,000$ a mile fences will be expensive but the burro controversy will be closed.

The moral of the story may be that sentimental considerations and shortsighted scientific interests should not be allowed to inhibit objective conservation measures. If the Park Service had been permitted to continue a sensible policy towards the Death Valley burros this final and, many feel, inhumane solution might not be necessary.

\section{Acknowledgments}

The author wishes to thank Patricia Phillips and Peter G. Sanchez for advice and assistance.

\section{References}

1. DOUGLAS, C.L. 1980. Co-operative National Park Resources Study Unit. Biennial Report No.13.4pp.

2. MOEHLMAN, P. de R. 1974. Behaviour and Ecology of Feral Assses. PhD Thesis, University of Wisconsin.

3. NATIONAL PARK SERVICE, 1981. Summary of Natural and Cultural Resources. Management Plan and Draft Environmental Impact Statement. Death Valley National Monument. 19pp.

4. WOODWARD, S.L. 1976. Feral Burros of the Chemehuevi Mountains, California: the Biogeography of a Feral Exotic. PhD Thesis, University of California at Los Angeles. 